\title{
Incremental Approach in Performance Based Budgeting - A Paradox in Indonesian Local Government: The Case of Aceh Province
}

\author{
Agustia Ferrira $^{1}$, Hasan Basri ${ }^{2}$, Heru Fahlevi ${ }^{3}$ \\ ${ }^{123}$ Faculty of Economics and Business, Syiah Kuala University, Indonesia.
}

\begin{abstract}
This study aims to evaluate the adoption of performance-based budgeting in Aceh provincial local government, Indonesia. Data was collected through a serial steps that includes documentation and interviews. The findings show that performance-based budgeting in Aceh government has not been fully implemented. The government units are still using incremental approach in allocating budget. The proportion of departments' budget are slightly changed over the years that indicates the incremental budgeting application.
\end{abstract}

Keywords: Performance-Based Budgeting, Incremental Budgeting.

\section{Introduction}

Indonesian local government financial systems have changed recently, along with many regulations and laws imposed by the government. These are, specifically, Indonesian Law Number 17 of 2003 concerning state finance, Indonesian Law 23 of 2014 concerning Regional Government, Government Regulation Number 58 of 2005 concerning Regional Financial Management, and Home Ministry Regulation Number 13 of 2006. As the regulations are implemented, the government improves the financial management system to make it more accountable, transparent, effective, and efficient. Budgeting is one of the most important parts of the government accounting system. Generally, in budgeting, there are 2 (two) approaches, namely, traditional budgeting and performance-based budgeting.

Traditional budgeting uses an additional approach, in which the budget is made based on addition and subtraction from the previous year's budget without assessment and analysis. Traditional budgets are arranged as line item budgets, which only focus on input, based on the inputs or resources that are used (Mardiasmo, 2009). Meanwhile, performance-based budgeting is a budgeting system that prioritizes performances in budget allocations. Performance-based budgeting is a budget that connects the state budget to desired results (the output or outcome) so that every dollar can be accounted for (Sancoko, 2008). Performance-based budgeting is an important thing since it will result in efficiency, effectiveness, and accountability in the use of public budgets, with clear outputs and outcomes based on national priorities so that all of the budgets can be shared transparently with the public.

However, performance-based budgeting has only been implemented in terms of technique and format, not at the level of paradigm and mindset (Rahayu, 2007). The same conditions were also found by the researcher in some Aceh Work Units in the Aceh Provincial Government. Based on the results of the initial observation and interviews with members of Aceh Work Units, it was shown that the Aceh Provincial Government has not implemented performancebased budgeting in managing Aceh's budget. Additionally, it is indicated from the incremental budgeting process that the budget has not included clear outputs and outcomes. Thus, there are some programs and activities that have not had plans put in the next budget, and there are some activities which are based on the previous budget. This is not in line with the government regulation which requires the implementation of performance-based budgeting. Additionally, it does not implement incremental budgeting in arranging the budget. The aim of this research is to analyze the implementation of performance-based budgeting in the government of Aceh Province.

This paper starts with a review of relevant literature, consisting of performance-based budgeting, the key elements of performance-based budgeting, the purpose of performance-based budgeting, the budgeting Process in Indonesian Local Governments, incremental budgeting, and the differences between traditional budgeting and performance-based budgeting. This is followed by a discussion of the research methods used. In Section Five, the findings are discussed, and finally, in Section Six, the paper provides a conclusion.

\section{Review of Selected Literature Performance-based budgeting}

Performance-based budgeting is a budgeting system that relates the budget of certain activities with the output and desired outcomes, including efficiency in achieving the outcomes of the output (Halim, 2007). In the explanation of Government Regulation Number 58 of 2005, it is stated that 
performance-based budgeting is a model of budgeting that prioritizes the results of work that the budget has been allocated for. This regulation means that all inputs in a budget must have a measurable result, and not be determined on how many funds are spent, as is applied in traditional budgeting models (incremental \& line-item budgets), but rather based on pre-determined performance.

\section{The Key Elements of Performance-based budgeting}

According to the Financial Education and Training Agency (2008, p. 10), in order to implement performance-based budgeting, there are key elements that must be determined in advance, namely a) vision and mission: vision is what the government wants to achieve in the long run, while mission is an illustration of how this vision will be achieved; b) purpose: which is a description of the vision and mission, as described in the medium term development plan or in Indonesia called "RPJM" which shows the steps that must be taken to achieve the vision and mission that has been set; c) target: specific and measurable steps needed to achieve the goals, which will help budget makers achieve their goals by setting specific and measurable targets; d) the program: which is a series of activities that will be carried out to achieve the goals, which are divided into several activities and accompanied by target outputs and results; and finally e) activities: a series of services aimed at producing outputs and results to achieve the program's aims.

\section{Purpose of Performance-based budgeting}

The purpose of performance-based budgeting is creating effectiveness and efficiency in utilizing a public expenditure budget with appropriate outputs and results according to the main needs of the region. Thus, every budget will be revealed transparently to the public (Taufiqurrahman, 2014). The purpose of implementing performance-based budgeting is to be able to show the relationship between funding and performance, increasing accountability and flexibility in carrying out tasks, managing budgeting, and increasing efficiency and transparency in its implementation (Directorate of Regional Financial Management Supervision, 2005).

\section{Budgeting Process in Local Governments in Indonesia}

Local government budget or APBD is the form or basis in managing regional finances in a particular fiscal year, generally planned for one fiscal year. As for the regional budget planning and drafting process, the approach adopted is a performance-based budget approach. The performancebased approach includes: targets according to the expenditures; service standards, estimated unit costs, and related activities, as well as regional budget revenue sources for expenditures. Based on the Regulation of the Ministry of Home Affairs Number 13 of 2006, t the Regional Budget is the annual financial plan of a regional government, which will be discussed and subsequently agreed upon jointly by the Regional Head and the Chairperson of the Regional
People's Representative Assembly (DPRD in Indonesian), and subsequently promulgated into regional regulations (Saragih, 2003). Regional budgets have some distinctive elements, namely: there is a source of income as a minimum target to cover the costs associated with carrying out these activities, as well as the maximum cost of expenses incurred, the types of activities described in numbers, and the annual budget period (Halim, 2007). According to Indonesian Constitution Number 17 of 2003 concerning the steps of regional budgeting:

1. The regional government submits the General Budget Policy (KUA) for the next fiscal year in line with the Regional Government Work Plan (RKPD), as the basis for preparing the Regional Budget to the DPRD no later than the middle of June of the current year;

2. The DPRD discusses the General Budget Policy submitted by the regional government in the preliminary discussion of the next year's Regional Budget;

3. Based on the General Budget Policy that has been agreed upon with the DPRD, the regional government together with the DPRD discusses the Temporary Budget Priorities and Ceiling (PPAS) to be used as a reference for each SKPD;

4. In planning the Regional Budget, the head of the SKPD as the budget user prepares the SKPD work plan and budget for the following year;

5. The SKPD work plan is prepared with an approach based on the work performance to be achieved;

6. The SKPD work plan and budgets are submitted to the DPRD to be discussed in the preliminary discussion of the Regional Budget;

7. The results of the RKA discussion are submitted to the Regional Financial Management Officials (PPKD) as the material for drafting the regional regulations for the following year's Regional Budget;

8. The regional government submits a draft of the regional regulations on the State Budget, accompanied by the explanations and supporting documents to the DPRD in the first week of October of the previous year;

9. The DPRD can submit proposals that result in changes in the amount of revenue and expenditures in the draft of regional regulations on the Regional Budget;

10. Decision making by the DPRD regarding the draft of the regional regulations on the State Budget is carried out no later than one month before the relevant fiscal year is implemented.

\section{Incremental Budgeting}

Incremental budgeting is a budgeting model that can change during the current year and is the basis for determining future budget proposals. Jones and Pendlebury in Syarifuddin (2003) state that there are 3 reasons why this model is still implemented, namely: 1) it includes many 
activities/programs used to achieve a government's goals in the previous year which need to be continued during the current year; 2) it is an easy way to avoid conflicts between units in government; 3) it is a very conservative way of implementing relatively small changes based on adequate consideration. The advantage of this method is its easy and fast usage, which is only based on the incremental budget and the previous year. However, the disadvantage is that it allows income and expenditures which are not in line with reality.

\section{Differences between Traditional Budgeting and Performance-Based Budgeting}

According to Mardiasmo (2009), there are significant differences between these two models, which can be seen in Table 1 below:

Table 1. Differences between Traditional Budgeting and Performance-Based Budgeting

\begin{tabular}{|l|l|}
\hline $\begin{array}{l}\text { Traditional Budgeting that still Implements } \\
\text { Incremental Budgeting }\end{array}$ & $\begin{array}{l}\text { Budgeting in the Era of NPM that Implements Performance } \\
\text { Budgeting }\end{array}$ \\
\hline $\begin{array}{l}\text { Full authority of the government lies completely with } \\
\text { the Central Government }\end{array}$ & $\begin{array}{l}\text { Policies are submitted from the central government to local } \\
\text { governments to regulate their own households }\end{array}$ \\
\hline Monitoring input & Monitoring inputs, outputs and results \\
\hline Not related to the Long-term Plan & Comprehensive and intact according to long-term planning \\
\hline Incremental and Line Item & Based on targets \\
\hline Limited Department (strict) & Cross department \\
\hline Using classical rule of vote accounting & Zero-based budgeting and programmed budgeting system planning \\
\hline Principle of gross budgeting & Rational and systematic \\
\hline Annual Budgeting & Bottom-up Budgeting \\
\hline Specific & $\begin{array}{l}\text { The ability to adapt and to work effectively in different situations } \\
\text { and with various individuals or groups }\end{array}$ \\
\hline
\end{tabular}

Sources: Mardiasmo (2009, p.61)

\section{Research Method}

This study employs a qualitative research using a case study approach. The reason why this design is used in this study is that the implementation of performance-based budgets in the Aceh Provincial Government is an appropriate case to be studied and translated into certain dynamic situations, and a case study of the organization can be used to solve the problems. The object of this study is the Aceh Work Unit (SKPA) in the Aceh Provincial Government, which has a total of 20 SKPA, in which each SKPA consists of 1 (one) respondent who fulfills the main tasks and functions related to budgeting, namely, the Head of Program Section/Program Subdivision Head. This research uses primary and secondary data. Primary data were obtained from respondents by filling out questionnaires and data collection techniques in the form of semi-structured interviews and documentation, while secondary data were obtained through literature studies and documentation (Sugiyono, 2014). The scoring for the results of the questionnaires refers to the Hewlett-Packard theory, namely, by comparing the actual score with the ideal score so as to get the actual percentage. The actual score is the total score of respondents' answers filled in the questionnaire, while the ideal score is all respondents assumed to answer with the highest score (Narimawati, 2017). The categorization of the questionnaire results can be seen in Table 2 .

Table 2. Categorization of the Questionnaire Results

\begin{tabular}{|l|l|l|}
\hline Score & Categorization & Explanation \\
\hline $18-20$ & Very Good & $\leq 3$ negative answer \\
\hline $15-17$ & Good & $\leq 4$ or $\leq 6$ negative answer \\
\hline $11-14$ & Fair & $\leq 7$ or $\leq 10$ negative answer \\
\hline$\leq 11$ & Poor & $\leq 11$ negative answer \\
\hline
\end{tabular}

Based on the categorization of the questionnaire results, there was selected SKPA (or local government unit) included in the "Good" category and another SKPA included in the lowest category in the implementation of performance-based budgeting. After that, the informant was selected from the two SKPAs and combined with the information from the Head of the Budget Section and the Head of the Sub-Section for Budget Management of the
Aceh Financial Management Agency, the Head of the Bappeda Program Division, and Secretariat Member of Aceh Government Budget Team (TAPA) to implement data collection techniques through interviews. Interviews were conducted at the informant's office during working hours, and most of the results of the interviews were recorded and transcribed. 


\section{Findings and Discussions}

To understand the performance-based budgeting process and its implementation in the Aceh Provincial Government, researchers conducted surveys by distributing questionnaires to 20 staff members of Aceh Toolkit Work Units in the Aceh Provincial Government for respondents who were directly involved in the planning and budgeting of the Aceh Toolkit within the scope of the Aceh Government. Out of the 20 (twenty) questionnaires that were distributed, only 16 (sixteen) questionnaires were filled out and returned to the researcher. This is because when the researchers collected the results of the questionnaire, respondents who were expected to answer the questionnaire were not present because they were participating in the Musrenbang activities held at the Aceh Regional Development Planning Agency, and also because of the authors' limited time. The results can be seen in Table 3 .

Table 3.The Results of Research Questionnaires

\begin{tabular}{|c|l|c|l|}
\hline No & Name of SKPA & Average score & Category \\
\hline 1. & Aceh Department of Marine and Fisheries & 19 & Very Good \\
\hline 2. & Aceh National Unity and Political Agency & 19 & Very Good \\
\hline 3. & Aceh Department of Agriculture and Plantation & 19 & Very Good \\
\hline 4. & Department of Community and Village Empowerment & 19 & Very Good \\
\hline 5. & Aceh Disaster Management Agency & 19 & Very Good \\
\hline 6. & Aceh Financial Management Agency & 18 & Very Good \\
\hline 7. & Aceh Civil Service Agency & 18 & Very Good \\
\hline 8. & Aceh Development Planning Agency & 18 & Very Good \\
\hline 9. & Aceh Women's Empowerment and Child Protection Agency & 18 & Very Good \\
\hline 10. & Aceh Department of Health & 17 & Good \\
\hline 11. & Aceh Social Department & 17 & Good \\
\hline 12. & Aceh Department of Libraries and Archives & 15 & Good \\
\hline 13. & Aceh Department of Transportation & 15 & Good \\
\hline 14. & Aceh Department of Syariat Islam & 14 & Fair \\
\hline 15. & Aceh Department of Culture and Tourism & 14 & Fair \\
\hline 16. & Aceh Small and Medium Cooperative Enterprises Agency & 14 & Fair \\
\hline
\end{tabular}

Source: Processed Data, 2018.

The way in which researchers calculated the average scores and categories in the table above from the results of the questionnaires from 16 SKPA can be seen in Table 2. Based on the questionnaire analysis and the average scores, it can be generally said that in terms of budgeting in the SKPA, the Aceh Provincial Government has understood performance-based budgeting well, even though there are 5 (five) SKPA included in the "Good" and "Sufficient" categories, which were sampled by looking at budget implementation documents (DPA-SKPA) for 4 (four) years from 2015 to 2018, in order to analyze whether the budget compilers in some of these SKPAs practiced Incremental Budgeting. This can be seen in Table 4.

Table 4. The Proportion of the Budget Work Unit Compared to the Total Budget

\begin{tabular}{|c|c|c|c|c|c|c|c|c|}
\hline \multirow{2}{*}{$\mathrm{NO}$} & \multirow{2}{*}{ Name of Organization } & \multicolumn{4}{|c|}{ Fiscal Year } & \multirow[t]{2}{*}{ Variance } & \multirow{2}{*}{ Average } & \multirow[t]{2}{*}{ Std. Deviation } \\
\hline & & 2015 & 2016 & 2017 & 2018 & & & \\
\hline 1 & 2 & 3 & 4 & 5 & 6 & 7 & 8 & 9 \\
\hline 1 & $\begin{array}{l}\text { Aceh Department of Libraries } \\
\text { and Archives }\end{array}$ & 0.37 & 0.34 & 0.83 & 0.41 & 0.05 & 0.49 & 0.20 \\
\hline 2 & $\begin{array}{l}\text { Aceh Department of } \\
\text { Transportation }\end{array}$ & 1.52 & 0.88 & 0.76 & 1.38 & 0.14 & 1.13 & 0.32 \\
\hline 3 & $\begin{array}{l}\text { Aceh Department of Syariat } \\
\text { Islam }\end{array}$ & 0.28 & 0.20 & 0.41 & 0.36 & 0.01 & 0.31 & 0.08 \\
\hline 4 & $\begin{array}{c}\text { Aceh Department of Culture and } \\
\text { Tourism }\end{array}$ & 0.47 & 0.26 & 0.79 & 1.27 & 0.19 & 0.70 & 0.38 \\
\hline 5 & $\begin{array}{c}\text { Aceh Small and Medium } \\
\text { Cooperative Enterprises Agency }\end{array}$ & 0.58 & 0.53 & 0.36 & 0.28 & 0.02 & 0.44 & 0.12 \\
\hline
\end{tabular}

Source: Processed Data, 2018. 
Based on the table above, there are some SKPAs which have unchanged budget portion. These unites are the Aceh Department of Libraries and Archives, the Aceh Department of Transportation, the Aceh Department of Shariah Islam, the Aceh Department of Culture and Tourism, and the Aceh Small and Medium Cooperative Enterprises Agency. The results in the table indicate that the budget compilers in some of these SKPA still practice incremental budgeting in terms of budget preparation. It can be seen that in preparing the budgets, budget makers still use the previous year's budget as guidance in preparing the current budget, which is strengthened by the variance, the average, and the standard deviation, which only revolve around the numbers $(0.01$ 1.13 ).

The Aceh Government's budgeting process begins with the Development Planning Meeting (Musrenbang) coordinated by the Regional Planning and Development Agency (Bappeda), which is then followed by all SKPAs in the Aceh Government. Furthermore, the budgeting process starts by planning documents in the form of a Strategic Plan (RENSTRA) in each SKPA and the stipulation of the Annual Work Plan (RENJA) on each SKPA. Both the RENSTRA and RENJA refer to the Aceh Medium Term Development Plan (RPJMA) and the Aceh Government Work Plan (RKPA). This is in accordance with the results of research conducted by Silalahi (2012), who found that performance-based budgeting is proven by the process of arrangement and the stipulation of several planning documents in the form of Strategic Plans (RENSTRA) and the Annual Work Plan (RENJA) established at each SKPD. But the implementation of performance-based budgets in the new Aceh Government is limited to certain technical aspects and formats that have been implemented, and there have not been many changes in thinking paradigms. It can be seen that budget compilers still lack understanding in interpreting output and outcomes, so that the results of performancebased budgets have been totally wrong in terms of preparing performance indicators.

This is the same as the results of research conducted by Rahayu (2007), who found that in Indonesian provinces, the implementation of performance budgeting is only done at the level of technical changes and format, but the knowledge and mindset have not changed much.

The success of the implementation of performance-based budgets in the new Aceh Provincial Government is limited to meeting regulatory requirements in order to obtain budget allocations, without any major focus on performance targets in the form of outputs and outcomes that have previously been compiled. It is only conducted using the amount of expenditures (input) without looking at the results, benefits, and impacts of the program/activity.

This is the same as the results of research conducted by Andriani et.al (2012), who found that during budget implementation, there are still work units who think that spending the available budget is the goal, rather than the 1976 achievement of performance targets agreed to in the budget document.

In addition, after conducting interviews with a number of officials in several SKPA, it was found that the majority of officials stated that the Aceh Provincial Government had strong leadership and commitments from all organizational components for the successful implementation of performance-based budgeting.

\section{The Phenomenon of incremental budgeting in preparing the Budget of the Aceh Provincial Government}

Incremental Budgeting is simply adding or reducing the amount of rupiah in the pre-existing budget items using the previous year's data as a basis for adjusting the amount of additions or deductions without an in-depth study (Syarifuddin, 2003). In the Aceh Provincial Government, performance-based budgeting has not been carried out in accordance with applicable laws and regulations. In practice, there are still a number of SKPAs which still tend to use an Incremental Budgeting approach in planning and budgeting, and it is shown that the budget compilers in the Aceh Provincial Government have not yet fully changed their approach. This can be seen from the fact that there is still an SKPA that only compiles programs and activities in accordance with last year's programs and activities without monitoring and evaluating the implementation of these programs and activities.

This is in accordance with the results of previous studies conducted by Utari (2009), who found that in the practice of budgeting, there is still the tendency to use traditional budget. Likewise, the results of a study conducted by Puspitasari (2013) show that in the practice of budgeting in different region, there are still many symptoms of using traditional approaches, including unclear performance indicators and established programs, as well as ineffective programs conducted again the following year.

\section{Obstacles in the Implementation of Performance-Based Budgeting in Preparing the Provincial Budget of Aceh}

Based on the questionnaire and interview data, it was found that in the government of Aceh Province, there are several obstacles that affect the implementation of performancebased budgeting, namely the absence of clear rewards and sanctions for the performance of each SKPA, Budget Limitations, Limited Human Resources, and a Lack of Legislative Support. This is in line with the research conducted by Cipta (2011), who stated that there are several factors that influence the implementation of performancebased budgeting, namely limited funds, limited human resources (HR), a lack of legislative support, and weaknesses in performance data.Meanwhile, in Utari's (2009) study, it is also stated that there are several constraints and obstacles in performance-based budgeting, including (1) the fact that the SKPD structure has not provided sufficient space for the preparation of integrated planning and budgeting; (2) the fact that the budget team has 
not been fully involved in each planning stage; (3) the lack of knowledge, understanding, and motivation of employees to optimally implement a performance-based budget; (4) the limits of the regional budget.

\section{Conclusion and Suggestions}

It can be concluded that the performance-based budgeting process has not been implemented properly and has not been in accordance with the applied laws and regulations in the Aceh Provincial Government. In the preparation of local government budget, the Aceh local Government tends to use the Incremental Budgeting approach, which shows that the budget compilation paradigm in the Aceh local Government has not yet fully changed. This can be seen from the fact that Aceh working unit or SKPA still compile programs and activities in accordance with the previous year's programs and activities, with no monitoring or evaluation of the implementation of these programs and activities. This study also finds several obstacles hindering the implementation of performance-based budgeting in the government of Aceh, namely the absence of clear rewards and sanctions for the performance of each SKPA, limited budgets, limited human resources, and the lack of legislative support. Further research is recommended in order to be able to conduct observation and obtain a comprehensive picture about various aspects of budgeting in the local government. Further research can also make comparisons between several District/City Governments in order to obtain comprehensive research results, including a picture of differences and performance in each District and City Government.

\section{References}

1. Andriani, Wiwik \& Hatta Ermataty. (2012). Analysis of Performance-Based Budgeting Implementation at Central Government (Study at Padang State Polytechnic). Journal of Accounting and Management.

2. Cipta, H. (2011). Analysis of the Application of Performance Based Budgeting (Performance Based Budgeting) to Local Governments (Explorative Studies in the Tanah Datar District Government). Thesis. Padang: Postgraduate Program of Andalas University.

3. Directorate of Regional Financial Management Supervision 3. 2005. Guidelines for PerformanceBased Budgeting (Revised). Jakarta: Deputy BPKP.

4. Financial Education and Training Agency (BPPK). 2008. Performance Measurement, An Overview of Government Agencies. Jakarta.

5. Government Regulation Number 58 of 2005 concerning Regional Financial Management.

6. Halim, A. (2007). Regional Financial Accounting. Third Edition. Jakarta: Salemba Empat.
7. Halim, A, \& M. Iqbal. (2012). Regional Financial Management. Yogyakarta: STIM YKPN.

8. Law of the Republic of Indonesia Number 17 of 2003 concerning State Finance.

9. Law Number 23 Year 2014 concerning Regional Government.

10. Mardiasmo. (2009). Public sector accounting. Yogyakarta: Andi Publisher.

11. Minister of Home Affairs Regulation Number 13 of 2006 concerning Guidelines for Regional Financial Management.

12. Narimawati, U. (2007). Human Resource Management Research. Jakarta: Agung Media.

13. Puspitasari, Ratna. (2013). Performance Based Budgeting Study in the East Java, West Java and DKI Jakarta Provincial Governments. Public Administration Network Journal, 2, 356-369.

14. Rahayu, S. Ludigdo, U. \& Affandy, D. (2007). Phenomenological Study of Regional Budgeting Process (Empirical Evidence from One Regional Work Unit in Jambi Province). National Accounting X Symposium, Makassar.

15. Sancoko, B. (2008). Study of Performance-Based Budgeting in Indonesia. Financial Education and Training Agency. Republic of Indonesia Ministry of Finance.

16. Saragih, Juli Panglima. (2003). Fiscal and Financial Decentralization in the RegionAutonomy. Jakarta: Ghalia Indonesia Publisher

17. Silalahi, U. (2012). Social Research Methods. Bandung: Refika Aditama.

18. Sugiyono. (2014). Quantitative, Qualitative Research Methods and R \& D. Bandung: Alfabeta.

19. Syarifuddin. (2003). Budget Models in Public Sector Organizations and their Development. Paper presented at the Monthly Seminar in the Accounting Department of the Faculty of Economics, Hasanuddin University, Makassar.

20. Taufiqurrahman. (2014). Performance-Based Budget Implementation in Local Governments: Challenges and Barriers. Public Administration Network, Year VI, 2, 511-519.

21. Utari, Nuraeni. (2009). Phenomenological Study of the process of Performance-Based Budgeting in the Temanggung Regency Government, Thesis. Semarang: Postgraduate Program at Diponegoro University.

22. Widyantoro, A. E. (2009). Implementation of Budgeting Performance Base: A Phenomenological Study (Case Study at Diponegoro University), Thesis. Semarang: Postgraduate Program at Diponegoro University. 